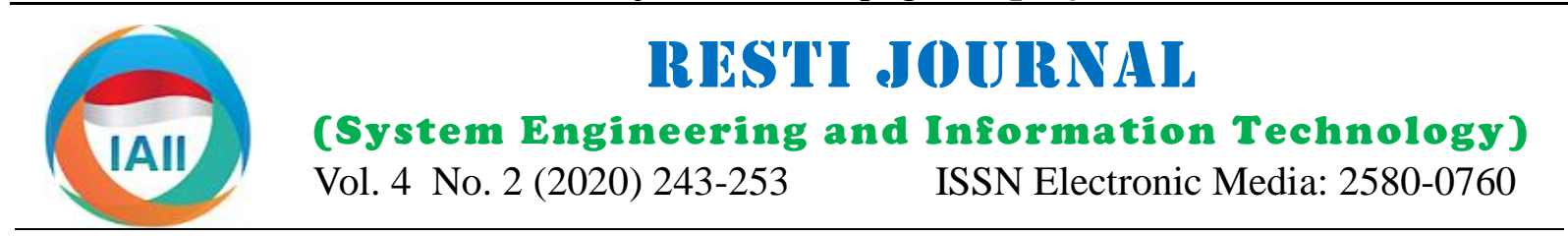

\title{
Evaluation of E-Government Maturity Models in Sub-District Public Services in Indonesia Using the SPBE Framework
}

\author{
I Made Sukarsa ${ }^{1}$, Ida Bagus Ananda Paramartha ${ }^{2}$, Anak Agung Ketut Agung Cahyawan ${ }^{3}$, Kadek Suar Wibawa ${ }^{4}$, \\ Putu Gede Arya Sumertha Yasa ${ }^{5}$, Ni Made Swasti Wulanyani ${ }^{6}$, Ni Wayan Wisswani ${ }^{7}$ \\ ${ }^{1234}$ Department of Information Technology, Engineering Faculty, Udayana University \\ ${ }^{5}$ Department of Law Science, Law Faculty, Udayana University \\ ${ }^{6}$ Department of Psychology, Medicine Faculty, Udayana University \\ ${ }^{7}$ Department of Informatic Management, Bali State Polytechnic \\ ${ }^{1}$ sukarsa@unud.ac.id, ${ }^{2}$ ananda.paramartha@ @student.unud.ac.id, ${ }^{3}$ agung.cahyawan@unud.ac.id, ${ }^{4}$ suar_wibawa@unud.ac.id \\ arya_sumerthayasa@unud.ac.id, ${ }^{5}$ swastiwulan@unud.ac.id, ${ }^{7}$ wisswani@pnb.ac.id
}

\begin{abstract}
The administration of Indonesian public services has entered the era of Industrial Revolution 4.0, which is a collaborative phase, requiring that every public service implement a service system base on digitization and integrated. The public service that has always been an open discussion is the PATEN SUb-District service. PATEN is a public service system that facilitates community access to get assistance related to population and licensing issues through the Sub-District. Based on PANRB Ministerial Regulation No. 5 of 2018 concerning SPBE Guidelines. SPBE is the framework of the Indonesian Government's Maturity Model, which assesses the level of maturity index in Local Government services. SPBE implementation only stops at the District level and has not touched the Sub-District level, so the SPBE research conducted on public services in the SubDistrict. SPBE maturity evaluation has been re-mapped in public services so that not all domains and indicators used. Based on the SPBE mapping results, it produces two domains and four indicators that will use as an assessment of maturity. The data collection method used was a questionnaire. The results showed the evaluation of the maturity of the SPBE in public services in the Sub-District obtained a "Poor" category with a total index value of 1.47. Accordingly, it was necessary to provide recommendations and improvement strategies to increase the value of the SPBE index.
\end{abstract}

Keywords: E-Government Maturity Model, SPBE, Sub-District, Public Service, Maturity Level

(C) 2020 RESTI Journal

\section{Introduction}

Nowadays, the organization of public services in Indonesia has entered a new era called the Industrial Revolution 4.0 [1], [2]. The industrial revolution 4.0 is a collaborative phase which requires that the entire service process has been carried out digitally and integrated [3]. The priority development in the current acc Indonesian Government is the public service sector [4]. issues. The application of PATEN services is currently Public services play an important role in activities still experiencing problems, found several critical organized by the Central, Regional, and Environmental points, such as limited human resource competence, Governments to meet the basic needs of every citizen slow service access, and poor business processes [9]. [5], [6]. Referring to Law Number 25, the Year 2009 This problem has led to public dissatisfaction with regarding Public Services is a series of public service public services provided by the Sub-District.

activities organized by the Government to fulfill the function to realize the benefit and needs of the community as a benchmark for the implementation of good governance [7].
In following up on public services, the Ministry of Home Affairs of the Republic of Indonesia issued Regulation of the Minister of Home Affairs Number 4 of 2010 regarding PATEN to manage public services at the Sub-District level [8].

Based on the critical point found in the public service sector of the Sub-District. The Central Government issued a new standard to strengthen public services as stipulated in the Regulation of the Minister of Administrative Reform and Bureaucratic Reform of the

Accepted by Editor: 21-03-2020 | Final Revision: 19-04-2020 | Online Publication : 20-04-2020 
I Made Sukarsa, Ida Bagus Ananda Paramartha, Anak Agung Ketut Agung Cahyawan, Kadek Suar Wibawa, Putu Gede Arya Sumertha Yasa, Ni Made Swasti Wulanyani, Ni Wayan Wisswani

RESTI Journal (System Engineering and Information Technology) Vol. 4 No. 2 (2020) 243 - 253

Republic of Indonesia Number 5 of 2018 concerning SPBE Guidelines. SPBE is the framework of the Indonesian Government's Maturity Model. SPBE evaluation aims to assess the level of maturity index.

SPBE assessments in Indonesia are only done at the District level and have not touched the Sub-District level. Therefore, conducting research related to the evaluation of best practices and alignment of SPBE implementation at the Sub-District level and the application of PATEN services, which serve as the basis for controlling public services in the Sub-District.

\section{Research Method}

Research methodology is the stages and procedures to ensure that the research process can be carried out regularly, systematically, controlled and directed [10]. The steps of the research carried out refer to the SPBE Guidelines for Regulation of the Minister of Administrative Reform and Republic of Indonesia Number 5 Year 2018 [11].

\subsection{Survey of Existing Public Service Conditions}

Survey of existing public service conditions is the initial stage of research conducted to collect data. The conditions for implementing a bureaucratic public service Sub-District can be in the form of business processes, service integration, critical points, and service quality standards.

\subsection{Literature Research}

Literature research is a stage that is performed to The SPBE assessment structure divided into three parts, explore the problems found during the SPBE research. namely domains, aspects, and indicators [13]. The Survey data collection can be in the form of tracking explanation of the three assessment structures is as critical points of service, collecting applicable policies follows. and regulations as well as related literature studies.

Literature research in this study can consist of Survey three main domains, namely, Internal Policy, SPBE of Existing Public Service Conditions, Literature study, Governance, and SPBE Services.

SPBE Framework Development, Map of Existing Business Process to SPBE, Data Collection in the form of General Questionnaire and Maturity Questionnaire, Data Analysis, Recommendations and Improvement Strategies.

\subsection{SPBE Framework Development}

Aspect is the specific areas of SPBE implementation assessed. SPBE has 7 aspects in the evaluation process, namely Internal Governance Policy, Internal Services Policy, Institutions, Strategy and Planning, Information and Communication Technology, Government Administration, and Public Services.

Based on Presidential Regulation of the Republic of Indicators is specific information regarding aspects of Indonesia Number 95 of 2018 concerning Electronic- the SPBE being assessed. SPBE has 35 overall Based Government Systems, or called SPBE, is a indicators in the SPBE Evaluation. government organization that uses information and communication technology to provide services for SPBE users [12]. SPBE is a framework for measuring Map of existing business process to SPBE is the the level of maturity at the Central and Local selection of 35 SPBE maturity indicators that Government Agencies used explicitly in Indonesia. The correspond to the public service business process at the assessment structure of the SPBE consists of domains, Sub-District level. Indicators of the level of maturity aspects, and indicators. The SPBE assessment structure can be in the form of an SPBE maturity questionnaire chart in Figure 2. obtained after the SPBE mapping process. A maturity 
questionnaire will be given to employees and staff in the Sub-District public services.

\subsection{Data Collection}

Data collection is done by interviews, observations, documentation, and questionnaires. Interview is a method of data collection that is done by giving several questions directly to the interviewees. The interview process was conducted with employees, officials, and staff at the Sub-District level. The purpose of the interview is to obtain an existing data set and business process services that are operating at the government agency.

Observation is a method of collecting data by making direct observations to the Sub-District service level to determine business processes and the structure of the Sub-District public service operation units.

Documentation is a method of collecting data by collecting several documents that are used as research material such as service standards, standard operational procedures, policies that operate in government agencies, as well as other documents related to SPBE.

The questionnaire is a method of data collection by giving several questions that have concluded in writing to respondents. The dissemination process completed by determining the respondents to whom the questionnaire will given. Respondents who participated in this questionnaire were Officers, Civil Servants, and Staff in the Sub-District.

The design of the questionnaire used was a standardized questionnaire that had been adjusted to the SPBE Evaluation Guidelines for Central Institutions and Local Governments by the Ministry of Administrative Reform and Bureaucracy Reform. The stages of questionnaire distribution divided into two phases.

The first questionnaire was a general questionnaire that used to find out the general condition of SPBE implementation at the District level. The respondent from the general questionnaire was the Head of the Communication System Deployment Section in the EGovernment Sector at the District Communication and Information Office as the center of information technology management in the Badung Regency Government. An example of a general questionnaire provided can explain in the following table.

Table 1. General Questionnaire

\section{General Questionnaire}

Make a list of applications that are use to implement internal management of the bureaucracy and public services in their respective Central / Regional Government Agencies.

The second questionnaire was an SPBE maturity level questionnaire at the Sub-District level. This questionnaire was selected based on the results of the mapping between the SPBE indicators and PATEN. An example of a maturity questionnaire provided can explain in the following table.

Table 2. Maturity Questionnaire



\subsection{Data Analysis}

Data analysis is the process of recapitulating the results of the SPBE maturity index value generated through the SPBE business process maturity questionnaire distributed previously.

SPBE maturity level assessment divided into two, namely process capability maturity level and function capability maturity level. The explanation of each level of maturity will discuss as follows.

Table 3. Process Capability Maturity Level

\begin{tabular}{|c|c|}
\hline Level & Characteristics \\
\hline $1-$ Stub & $\begin{array}{l}\text { Internal policies are not yet available or are } \\
\text { still in conceptual form. } \\
\text { Governance is carried out at any time and is } \\
\text { not well organized without monitoring and } \\
\text { unpredictable results. }\end{array}$ \\
\hline 2 - Managed & $\begin{array}{l}\text { Internal policies have been legalized, but } \\
\text { the arrangements are partial or sectoral. } \\
\text { Governance is carried out on the basis of } \\
\text { management that has been defined and } \\
\text { documented, it is implemented according to } \\
\text { the standards of each organizational unit. }\end{array}$ \\
\hline 3 - Standardized & $\begin{array}{l}\text { Internal policy has set the standard } \\
\text { governance process for all organizational } \\
\text { units, but has not yet set the alignment } \\
\text { between governance processes. } \\
\text { Governance is fully implemented by } \\
\text { standardization by all relevant } \\
\text { organizational units. }\end{array}$ \\
\hline $\begin{array}{l}4 \text { - Integrated and } \\
\text { Measured }\end{array}$ & $\begin{array}{l}\text { Internal policies have arranged integration } \\
\text { between governance processes and } \\
\text { mechanisms for measuring the performance } \\
\text { of governance processes. }\end{array}$ \\
\hline & $\begin{array}{l}\text { Governance is integrated with other } \\
\text { governance processes and measuring } \\
\text { performance quantitatively. }\end{array}$ \\
\hline 5-Optimum & $\begin{array}{l}\text { Internal policies have set the mechanism } \\
\text { for continuous evaluation and change } \\
\text { management. } \\
\text { Governance is carried out with continuous } \\
\text { quality improvement. }\end{array}$ \\
\hline
\end{tabular}


Process capability maturity level is a guideline for 3.1. Potrait Service Integration determining the level of maturity in Domain Internal Policy and Domain SPBE Governance. There are five levels of maturity in the process capability maturity level, namely the stub, managed, standardized, integrated and measured, and optimum. The level of maturity in the function capability maturity level can be seen in Table 4.

Table 4. Function Capability Maturity Level

\begin{tabular}{cl}
\hline \multicolumn{1}{c}{ Level } & \multicolumn{1}{c}{ Criteria } \\
\hline 1- Information & $\begin{array}{l}\text { SPBE services are provided in the form of } \\
\text { one-way information } \\
\text { SPBE services are provided in the form of } \\
\text { two-way interactions } \\
\text { SPBE services are provided through the } \\
\text { exchange of information and services } \\
\text { SPBE services are provided through } \\
\text { 4- Collaboration }\end{array}$ \\
$\begin{array}{l}\text { integration with other SPBE services } \\
\text { SPBE services can adapt to changing needs } \\
\text { in the internal and external environment }\end{array}$ \\
\hline
\end{tabular}

Function capability maturity level is a guideline for admitting the level of maturity in the SPBE service domain. There are five levels of maturity in the function capability maturity level, namely the level of information, interaction, transaction, collaboration and optimization.

SPBE maturity index predicate is a value that represents the maturity level of the implementation of SPBE which is grouped based on the predicate that can be explained in Table 5.

Table 5. SPBE Maturity Index Predicate

\begin{tabular}{ll}
\hline \multicolumn{1}{c}{ Maturity Index } & \multicolumn{1}{c}{ Predicate } \\
\hline $4.2-5.0$ & Excellent \\
$3.5-<4.2$ & Very Good \\
$2.6-<3.5$ & Good \\
$1.8-<2.6$ & Average \\
$<1.8$ & Poor \\
\hline
\end{tabular}

\subsection{Reccomendation and Improvement Strategy}

Recommendations and improvement strategies are the final stages to provide improvement recommendations to improve the quality of governance and public service standards.

\section{Result and Discussion}

This chapter describes the results and discussion of the research about the SPBE to find out the scope of the SPBE implementation conditions at the Sub-District level. SPBE Analysis can consist of Service Integration Portrait, General Questionnaire Results, Map of Existing Business Process to SPBE, Maturity Level Assessment, Recommendations and Improvement Strategies.

The portrait of service integration is the level of business implementation of the Sub-District public service process. The business process is carried out through several levels starting from Hamlet, Village, Sub-District and District. Explanation of each business public service process can be seen in the following table.

\begin{tabular}{|c|c|c|}
\hline No & Public Services & $\begin{array}{c}\text { Service Integration } \\
\text { Level (Location) }\end{array}$ \\
\hline 1 & Electronic Identity Card & $\begin{array}{l}\text { Hamlet, Village, Sub- } \\
\text { District, District }\end{array}$ \\
\hline 2 & $\begin{array}{l}\text { New Family Card for } \\
\text { Indonesian Citizens }\end{array}$ & $\begin{array}{l}\text { Hamlet, Village, Sub- } \\
\text { District, District }\end{array}$ \\
\hline 3 & $\begin{array}{l}\text { Renewal of Family Card Data } \\
\text { for Indonesian Citizens }\end{array}$ & $\begin{array}{l}\text { Hamlet, Village, Sub- } \\
\text { District, District }\end{array}$ \\
\hline 4 & $\begin{array}{l}\text { Family card lost and corrupted } \\
\text { for Indonesian Citizens }\end{array}$ & Hamlet, Sub-District \\
\hline 5 & $\begin{array}{l}\text { Certificate of Transference of } \\
\text { the Inter-District / Inter- } \\
\text { Province }\end{array}$ & $\begin{array}{l}\text { Hamlet, Village, Sub- } \\
\text { District }\end{array}$ \\
\hline 6 & $\begin{array}{l}\text { Certificate of Transference } \\
\text { Appearing of the Inter-District } \\
\text { / Province }\end{array}$ & Village, Sub-District \\
\hline 7 & $\begin{array}{l}\text { Certificate of Transference } \\
\text { between Sub-District in the } \\
\text { District }\end{array}$ & $\begin{array}{l}\text { Hamlet, Village, Sub- } \\
\text { District }\end{array}$ \\
\hline 8 & $\begin{array}{l}\text { Certificate of Transference } \\
\text { Appearing of the Village / } \\
\text { Village Office in one District }\end{array}$ & $\begin{array}{l}\text { Hamlet, Village, Sub- } \\
\text { District }\end{array}$ \\
\hline 9 & $\begin{array}{l}\text { Certificate of Transference } \\
\text { Appearing of the Village / } \\
\text { Village Office in one Sub- } \\
\text { District }\end{array}$ & Village, Sub-District \\
\hline 10 & $\begin{array}{l}\text { Population Administration for } \\
\text { Foreign Citizens }\end{array}$ & Sub-District, District \\
\hline 11 & $\begin{array}{l}\text { Certificate of Population } \\
\text { Problems }\end{array}$ & $\begin{array}{l}\text { Hamlet, Village, Sub- } \\
\text { District }\end{array}$ \\
\hline 12 & $\begin{array}{l}\text { Comparative } \quad \text { Building } \\
\text { Construction Permit, Business } \\
\text { Place Certificate }\end{array}$ & $\begin{array}{l}\text { Hamlet, Village, Sub- } \\
\text { District, District }\end{array}$ \\
\hline 13 & $\begin{array}{l}\text { Land Heritage Service for } \\
\text { Confirmation of Rights / } \\
\text { Issuance of SPPT }\end{array}$ & $\begin{array}{l}\text { Hamlet, Village, Sub- } \\
\text { District, District }\end{array}$ \\
\hline 14 & $\begin{array}{lr}\text { Social Assistance } & \text { Proposal } \\
\text { Services and } & \text { other } \\
\text { Recommendations } & \end{array}$ & $\begin{array}{l}\text { Hamlet, Village, Sub- } \\
\text { District }\end{array}$ \\
\hline
\end{tabular}

Table 6 shows the level of integration of fourteen business processes in the Sub-District PATEN service. The level of the business process in the subject process that the community goes through starting from the preparation of a covering letter that complete at the hamlet and village level, then finishing the requirements file at the Sub-District level. The community give optional, which to wait for the procedure in the Sub-District or directly come to the District.

\subsection{Summary General Questionnaires}

The general questionnaire is a method used to collect data related to general SPBE implementation conditions at the Sub-District level. General 
I Made Sukarsa, Ida Bagus Ananda Paramartha, Anak Agung Ketut Agung Cahyawan, Kadek Suar Wibawa, Putu Gede Arya Sumertha Yasa, Ni Made Swasti Wulanyani, Ni Wayan Wisswani

RESTI Journal (System Engineering and Information Technology) Vol. 4 No. 2 (2020) 243 - 253

questionnaires can be in the form of a list of general application practices that are used by the Regional Organizations of the Central Government. A list of general applications can explain in Table 7.

Table 7. Application List

\begin{tabular}{ll}
\hline \multicolumn{1}{c}{ Functional Application } & \multicolumn{1}{c}{ Application Name } \\
\hline $\begin{array}{l}\text { Asset Information System and } \\
\text { Regional Goods }\end{array}$ & Simda Barang \\
$\begin{array}{l}\text { Financial Information System } \\
\text { (e-Budgeting) }\end{array}$ & Simda Keuangan \\
$\begin{array}{l}\text { Supervision } \quad \text { Information } \\
\text { System }\end{array}$ & LAPOR SP4N, Whistle \\
$\begin{array}{l}\text { Personnel Information System } \\
\text { Population Information }\end{array}$ & SIMPEG, BKPSDM \\
$\begin{array}{l}\text { System } \\
\text { Recording System }\end{array}$ & SIAK \\
Printing System & BEnroller \\
& BCardManagement \\
\hline
\end{tabular}

Table 7 explains the result of list general application services available at the Government at the Regency level based on the general questionnaire that has been filled out by respondents. The list of services reveals that there are six applications managed by the SubDistrict. In addition, there are some internal public services operated by the work unit on PATEN public services. The applications are SIAK, BEnroller, BcardManagement.

\subsection{Map of Existing Business Process to SPBE}

The map of existing business process to SPBE is performed in accordance with the SPBE evaluation guidelines. The evaluations are performed based on the SPBE assessment strucuture. The mapping process was performed in order to obtain the existing SPBE indicators in the PATEN service at the Sub-District level. Sign $(x)$ shows the indicators that are not related to PATEN and signs $(y)$ shows the indicators that are related to PATEN. The mapping process can be explained in Table 8.

Table 8. Map Existing Business Process to SPBE

\begin{tabular}{|c|c|}
\hline Indicators SPBE & PATEN \\
\hline $\begin{array}{c}\text { Domain } 1 \text { Internal Policy } \\
\text { Aspect } 1 \text { SPBE Governance Internal Policy }\end{array}$ & \\
\hline $\begin{array}{l}\text { Indicators } 1 \text { Internal Policy of the Government } \\
\text { Agency SPBE Steering Team }\end{array}$ & $x$ \\
\hline $\begin{array}{l}\text { Indicators } 2 \text { Internal Policy Integrated Business } \\
\text { Process Innovations }\end{array}$ & $x$ \\
\hline $\begin{array}{l}\text { Indicators } 3 \text { Internal Policy of the Government } \\
\text { Agency SPBE Master Plan }\end{array}$ & $x$ \\
\hline $\begin{array}{l}\text { Indicators } 4 \text { ICT Internal Budgeting and Expenditure } \\
\text { Policy }\end{array}$ & $x$ \\
\hline Indicators 5 Internal Data Operations Policy & $x$ \\
\hline $\begin{array}{l}\text { Indicators } 6 \text { Internal Application System Integration } \\
\text { Policy }\end{array}$ & $x$ \\
\hline $\begin{array}{l}\text { Indicators } 7 \text { Internal Policy on Use of General } \\
\text { Applications for Sharing }\end{array}$ & $x$ \\
\hline Aspect 2 SPBE Service Internal Policy & \\
\hline Indicators 8 Internal Policy of Manuscript Services & $x$ \\
\hline $\begin{array}{l}\text { Indicators } 9 \text { Internal Staffing Management Services } \\
\text { Policy }\end{array}$ & $x$ \\
\hline $\begin{array}{l}\text { Indicators } 10 \text { Internal Policy of Planning and } \\
\text { Budgeting Management Services }\end{array}$ & $x$ \\
\hline
\end{tabular}

\begin{tabular}{|c|c|}
\hline Indicators SPBE & PATEN \\
\hline $\begin{array}{llllll}\text { Indicators } & 11 & \text { Internal } & \text { Policy } & \text { of } & \text { Financial }\end{array}$ & $x$ \\
\hline $\begin{array}{l}\text { Management Services } \\
\text { Indicators } 12 \text { Internal Policy of Performance } \\
\text { Management Services }\end{array}$ & $x$ \\
\hline Indicators 13 Internal Procurement Services Policy & $x$ \\
\hline $\begin{array}{l}\text { Indicators } 14 \text { Internal Public Service Complaints } \\
\text { Policy }\end{array}$ & $x$ \\
\hline $\begin{array}{l}\text { Indicators } 15 \text { Internal Policy Documentation and } \\
\text { Legal Information Services }\end{array}$ & $x$ \\
\hline $\begin{array}{l}\text { Indicators } 16 \text { Internal Policy of the Whistle Blowing } \\
\text { System Service }\end{array}$ & $x$ \\
\hline $\begin{array}{l}\text { Indicators } 17 \text { Internal Policy of Public Services of } \\
\text { Government Agencies }\end{array}$ & $x$ \\
\hline $\begin{array}{c}\text { Domain } 2 \text { SPBE Governance } \\
\text { Aspect } 3 \text { Institutional }\end{array}$ & \\
\hline $\begin{array}{l}\text { Indicators } 18 \text { Government Agency SPBE Steering } \\
\text { Team }\end{array}$ & $x$ \\
\hline $\begin{array}{c}\text { Indicators } 19 \text { Integrated Business Process Innovations } \\
\text { Aspect } 4 \text { Strategy and Planning }\end{array}$ & $x$ \\
\hline $\begin{array}{l}\text { Indicators } 20 \text { SPBE Master Plan for Government } \\
\text { Agencies }\end{array}$ & $x$ \\
\hline $\begin{array}{l}\text { Indicators } 21 \text { ICT Budget and Expenditures } \\
\text { Aspect } 5 \text { ICT }\end{array}$ & $x$ \\
\hline Indicators 22 Data Center Operations & $x$ \\
\hline Indicators 23 Application System Integration & $x$ \\
\hline $\begin{array}{c}\text { Indicators } 24 \text { Use of General Applications Sharing } \\
\text { Domain } 3 \text { SPBE Services } \\
\text { Aspect } 6 \text { Government Administration }\end{array}$ & $y$ \\
\hline Indicators 25 Service Manuscript Services & $x$ \\
\hline Indicators 26 Staffing Management Services & $x$ \\
\hline Indicators 27 Planning Management Services & $x$ \\
\hline Indicators 28 Budgeting Management Services & $x$ \\
\hline Indicators 29 Financial Management Services & $x$ \\
\hline Indicators 30 Performance Management Services & $x$ \\
\hline $\begin{array}{l}\text { Indicators } 31 \text { Procurement Services } \\
\text { Aspect } 7 \text { Public Services }\end{array}$ & $x$ \\
\hline Indicators 32 Public Complaints Service & $y$ \\
\hline $\begin{array}{l}\text { Indicators } 33 \text { Legal Documentation and Information } \\
\text { Services }\end{array}$ & $x$ \\
\hline Indicators 34 Whistle Blowing System service & $y$ \\
\hline Indicators 35 Public Service & \\
\hline
\end{tabular}

Table 8 explains the mapping process for all SPBE indicator items included in the PATEN Sub-District public services. The mapping results obtained by four indicators formed through two different domains, namely Domain 2 SPBE Governance and Domain 3 SPBE Services. The description of the results of the four indicators can be seen in Table 9.

Table 9. SPBE Indicator Mapping Result

\begin{tabular}{ll}
\hline Domain 2 & SPBE Governance \\
\hline Indicators 24 & Use of General Applications \\
& Sharing \\
Domain 3 & SPBE Services \\
Indicators 32 & Public Complaints Service \\
Indicators 34 & Whistle Blowing System \\
& Service \\
Indicators 35 & Public Service Government \\
& Agencies \\
\hline
\end{tabular}

\subsection{Maturity Level Assessment}

Maturity level assessment is a framework that measures the level of SPBE development. Based on the results of the mapping of SPBE business processes in the previous stage, two objective domains produced, 
I Made Sukarsa, Ida Bagus Ananda Paramartha, Anak Agung Ketut Agung Cahyawan, Kadek Suar Wibawa, Putu Gede Arya Sumertha Yasa, Ni Made Swasti Wulanyani, Ni Wayan Wisswani

RESTI Journal (System Engineering and Information Technology) Vol. 4 No. 2 (2020) 243 - 253

namely SPBE Governance and SPBE Services. Maturity level measurements carried out using a maturity questionnaire, the questionnaire given to the Head of the PATEN services section in the Sub-District and staff. The measurement process implemented according to the SPBE maturity assessment structure. The results of the index values in each domain are summed and averaged to produce domain values and SPBE values.

The domain of SPBE Governance is a framework that manages, directs, and controls the implementation of an integrated SPBE. The results of the SPBE Governance domain index can be seen in the following table.

Table 10. SPBE Governance Index

\begin{tabular}{cl}
\hline \multicolumn{1}{c}{ Indicators } & Index \\
\hline Indicators 24 Use of General Applications Sharing & 2 \\
Domain SPBE Governance & 2.00 \\
\hline
\end{tabular}

Table 10 shows the index value of the SPBE Governance Domain, which only has one indicator related to the PATEN service. The index value of the SPBE Governance domain obtained is 2.00 , with the predicate "Average".

Domain 3 SPBE Services is a function domain of the SPBE application system that provides benefits to SPBE users. SPBE Services has 11 indicators following the SPBE asssessment structure, after mapping the indicators that correspond to the PATEN, three indicators from the service domain obtained to assess the level of public service in the Sub-District PATEN. Based on the Service Integration Portrait, the SubDistrict has 14 public services, where public services will independently evaluate using the indicator 35 . The results of the SPBE Services domain index can describe in the following table.

Table 11. SPBE Services Index

\begin{tabular}{|c|c|}
\hline Indicators & Index \\
\hline Indicators 32 Public Complaints Service & 2 \\
\hline $\begin{array}{c}\text { Indicators } 34 \text { Whistle Blowing System Service } \\
\text { Indicators } 35 \text { Public Services (PATEN) }\end{array}$ & 3 \\
\hline $\begin{array}{l}\text { Indicators } 35 \text { Public Service } 1 \text { (Electronic Identity } \\
\text { Card) }\end{array}$ & 1 \\
\hline $\begin{array}{l}\text { Indicators } 35 \text { Public Service } 2 \text { (New Family Card for } \\
\text { Indonesian Citizens) }\end{array}$ & 1 \\
\hline $\begin{array}{l}\text { Indicators } 35 \text { Public Service } 3 \text { (Renewal of Family Card } \\
\text { Data for Indonesian Citizens) }\end{array}$ & 1 \\
\hline $\begin{array}{l}\text { Indicators } 35 \text { Public Service } 4 \text { (Family card lost and } \\
\text { corrupted for Indonesian Citizens) }\end{array}$ & 1 \\
\hline $\begin{array}{l}\text { Indicators } 35 \text { Public Service } 5 \text { (Certificate of } \\
\text { Transference of the Inter-District / Inter-Province) }\end{array}$ & 1 \\
\hline $\begin{array}{l}\text { Indicators } 35 \text { Public Service } 6 \text { (Certificate of } \\
\text { Transference Appearing of the Inter-District/ Province) }\end{array}$ & 1 \\
\hline $\begin{array}{l}\text { Indicators } 35 \text { Public Service } 7 \text { (Certificate of } \\
\text { Transference between Sub-District in the District) }\end{array}$ & 1 \\
\hline $\begin{array}{l}\text { Indicators } 35 \text { Public Service } 8 \text { (Certificate of } \\
\text { Transference Appearing of the Village / Village Office } \\
\text { in one District) }\end{array}$ & 1 \\
\hline $\begin{array}{l}\text { Indicators } 35 \text { Public Service } 9 \text { (Certificate of } \\
\text { Transference Appearing of the Village / Village Office } \\
\text { in one Sub-District) }\end{array}$ & 1 \\
\hline
\end{tabular}

\begin{tabular}{llll}
\hline \multicolumn{3}{c}{ Indicators } & Index \\
\hline $\begin{array}{l}\text { Indicators } 35 \quad \text { Public Service } \\
\text { Administration for Foreign Citizens) }\end{array}$ & (Population & 0 \\
Indicators 35 Public Service $11 \quad$ (Certificate of & 0 \\
$\begin{array}{l}\text { Population Problems) } \\
\text { Indicators 35 Public Service 12 (Comparative Building }\end{array}$ & 0 \\
$\begin{array}{l}\text { Construction Permit, Business Place Certificate) } \\
\text { Indicators 35 Public Service 13 (Land Heritage Service } \\
\text { for Confirmation of Rights / Issuance of SPPT) }\end{array}$ & 0 \\
Indicators 35 Public Service 14 (Social Assistance & 0 \\
Proposal Services and other Recommendations) & 0.93 \\
\hline \multicolumn{3}{c}{ Domain SPBE Services } \\
\hline
\end{tabular}

Table 11 shows the index value of the SPBE Services Domain. Based on the average of the indicator index value, the value obtained from the SPBE Services Domain is 0.93 with the predicate "Poor".

SPBE index is the result of calculating the average domain index value that represents the level of SPBE implementation. Based on the results obtained between domain SPBE Governance and domain SPBE Services, the quantity is done and produces an average that can be seen in the table as follows.

Table 12. SPBE Index

\begin{tabular}{lcc}
\hline & Domain & Index \\
\hline SPBE Governance & & 2.00 \\
SPBE Services & & 0.93 \\
& SPBE & 1.47 \\
\hline
\end{tabular}

Table 12 shows the results of the SPBE index value that has been implemented in the Sub-District with a value of 1.47 and the predicate "Poor".

\subsection{Recommendations and Improvement Strategies}

Recommendations for improvement are the strategies provided to improve business processes that experience a lack of index categories so that improvements produced to develop the quality of public services. The recommendations divided into several sections, which will be explained as follows.

\subsubsection{Improvement of SPBE Indicators}

The improvement of the SPBE indicator is a process to increase the index value of the SPBE indicator generated through the assessment of the maturity of the PATEN Sub-District public services.



Figure 3. Improvement Indicators SPBE

Figure 3 shows the indicators of improvements created to achieve the expected level of objectives. The 
I Made Sukarsa, Ida Bagus Ananda Paramartha, Anak Agung Ketut Agung Cahyawan, Kadek Suar Wibawa, Putu Gede Arya Sumertha Yasa, Ni Made Swasti Wulanyani, Ni Wayan Wisswani

RESTI Journal (System Engineering and Information Technology) Vol. 4 No. 2 (2020) 243 - 253

following is an explanation of the increase in each expected value of the SPBE Services Domain index is SPBE domain. 1.93.

Table 13. Improvement SPBE Governance Index

\begin{tabular}{lcc}
\hline \multicolumn{1}{c}{ Indicators } & Current & Expected \\
\hline $\begin{array}{l}\text { Indicators 24 Use of General } \\
\text { Applications Sharing }\end{array}$ & 2 & 3 \\
Index Domain SPBE Governance & 2.00 & 3.00 \\
\hline
\end{tabular}

Table 15. Result Improvement SPBE Index

\begin{tabular}{lcc}
\hline \multicolumn{1}{c}{ Domain } & Current & Expected \\
\hline SPBE Governance & 2.00 & 3.00 \\
SPBE Services & 0.93 & 1.93 \\
Index SPBE & 1.47 & 2.47 \\
\hline
\end{tabular}

Table 13 shows an improvement in the value of Table 15 shows the total SPBE index results. The indicators in the Domain SPBE Governance. The current condition of the SPBE index is at an index current condition in the SPBE Domain Governance has value of 1.47. Including an improvement in the level of an index value of 2.00, which is indicator 24 Use of each indicator, the expectation of the SPBE index value General Applications Sharing, the situation is still at is 2.47. Developing the level of each indicator is done level two, which means that the implementation by implementing recommendations and improvement process even at the basic level. Increasing the strategies in each domain, which will be explained as expectation level, which is the third level standardized, follows.

so the process of implementing governance must be regulated, requiring all service units to apply detailed standard procedures. The expected index value in the SPBE Governance Domain is 3.00.

Table 14. Improvement SPBE Services Index

\begin{tabular}{lcc}
\hline \multicolumn{1}{c}{ Indicators } & Current & Expected \\
\hline $\begin{array}{l}\text { Indicators 32 Public Complaints } \\
\text { Service }\end{array}$ & 3 & 4 \\
Indicators 34 Whistle Blowing & 3 & 4 \\
System Service & & \\
Indicators 35 Public Service 1 & 1 & 2 \\
Indicators 35 Public Service 2 & 1 & 2 \\
Indicators 35 Public Service 3 & 1 & 2 \\
Indicators 35 Public Service 4 & 1 & 2 \\
Indicators 35 Public Service 5 & 1 & 2 \\
Indicators 35 Public Service 6 & 1 & 2 \\
Indicators 35 Public Service 7 & 1 & 2 \\
Indicators 35 Public Service 8 & 1 & 2 \\
Indicators 35 Public Service 9 & 1 & 2 \\
Indicators 35 Public Service 10 & 0 & 1 \\
Indicators 35 Public Service 11 & 0 & 1 \\
Indicators 35 Public Service 12 & 0 & 1 \\
Indicators 35 Public Service 13 & 0 & 1 \\
Indicators 35 Public Service 14 & 0 & 1.93 \\
Index Domain SPBE Services & 0.93 & \\
\hline
\end{tabular}

Table 14 shows an improvement in the intended expectations of the previous level in the SPBE Services Domain. The current SPBE Services domain value has an index value of 0.93 , with 16 indicators, including Indicators 32 Public Complaints Service and Indicators 34 Whistle Blowing System Service is currently at the third level of transactions. The third level means that the service system process is carried out through information and service exchanges. So to improve to the fourth level, namely collaboration, the service system must create innovations by accompanying a collaboration between the current SPBE service system and other SPBE service systems.

Indicators 35 Public Service expectations on each The application of existing business processes must public service touch on level 1 information and level 2 have a written internal policy. The improvement interaction, which means there is already a one-way suggestions given are making decisions from each of and two-way access to public service systems. The the 14 public service business processes. The Decree

\subsubsection{Recommendation SPBE Governance}

The second improvement suggestion is the recommendation for improvement in Domain SPBE Governance. Suggestions for improvement are made to improve the governance of PATEN service in SubDistrict. The service provided for improvement suggestions is governance of services such as business processes, human resources, performance control evaluations, which can be explained in Table 14

Table 14. Recommendation SPBE Governance

\begin{tabular}{cl}
\hline No & \multicolumn{1}{c}{ Recommendations } \\
\hline 1 & Organizing SPBE PATEN Steering Team \\
2 & Suggesting PATEN Team Decree for each Service \\
3 & Create a Standard Procedure using General Sharing \\
& Applications \\
4 & Business Process Improvement \\
5 & Building Interactions and Communication Networks \\
6 & Strengthening SPBE Human Resources Services \\
7 & Evaluation of Peformance Control \\
8 & Reenginering Business Process towards Best Pratice \\
\hline
\end{tabular}

\subsubsection{Organizing SPBE PATEN Steering Team}

The SPBE Steering Team is a team that gives the task of controlling, directing, and evaluating SPBE, including the formulation of policies and the application of SPBE. The formation of the steering team at the Sub-District level aims to ensure that the SPBE implementation process from the Sub-District to the central goverment can operate well. The improvement suggestions given are to create an SPBE Steering Team, which consists of the Sub-District Secretary with the Section Chief, to build an effective collaboration.

3.5.2.2 Suggesting PATEN Team Decree for each Service

RESTI Journal (System Engineering and Information Technology) Vol. 4 No. 2 (2020) 243 - 253 
states the main tasks, functions, and responsibilities of through the Village Head, and validation using an the PATEN officer.

\subsubsection{Create a Standard Procedure using General} Sharing Applications

General sharing application is a regular application will bring up notifications to members that the used by local governments in carrying out their document has been completed.

business processes. Still, there is not yet a standard that is used as a reference. Improvements made are making standard general application procedures so that the process of using general applications can operate effectively.

\subsubsection{Business Process Improvement}

Standard Operating Procedure is a procedure that used as a guideline in conducting business processes, both for the Sub-District as a service provider and the community as a service recipient. An improvement in
SOP needs to be done, and it can be more detailed and provide best practice online PATEN services.

There are recommendations for improving SOP [14]. 3.5.2.6 Strengthening SPBE Human Resources Such as in the form of simplifying community mobility Services by using the system. The system can access the subvillage head level to the Village Head. Therefore, the community does not need to sign the relevant agency to request a signature. They only need to upload supporting documents for submission of requests and wait for the notification of file retrieval. The document validation can be done by using an Electronic Signature to speed up the validation process.

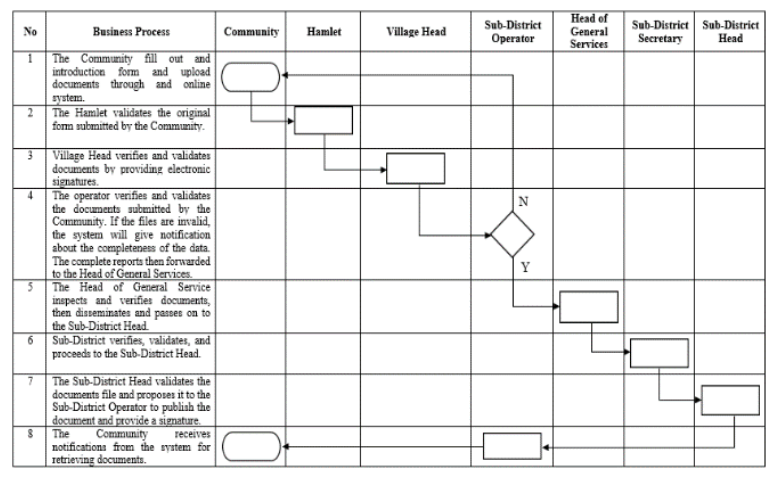

Figure 4. Business Process Improvement

The current condition that happens inside the PATEN service in the Sub-District is still doing the process manually, which means that the community must come to the location to process documents, this is very ineffective because in the digitalization era everything has been done online. Recommendations were made on the PATEN business process service by implementing an online service system. The community does not need to be complicated to look for a letter of introduction to the hamlet head and village head but only needs to submit documents through the system. The system will direct the process of document recognition validation
3.5.2.5 Building Interactions and Communication Networks

The implementation of PATEN services needs to build active interaction with the community, not only through dissemination services but also productive and open through sharing media platforms such as social media. The purpose of strengthening this communication is that the implementation of the PATEN public service can provide useful feedback to the community, such as the relationship of spreading information with the public can be well-received, and the submission of complaints can be resolved with the right solution.

HR Development (Human Resources) is a framework to help employees to develop the skills, abilities, cohesiveness, and knowledge of each individual. Increasing the potential of SPBE HR in the Sub-District environment can be done through improving the experience, applying SPBE best practices, developing a work culture based on SPBE, developing functional positions in Civil Servants, and implementing partnerships with multiple companies.

\subsubsection{Evaluation of Peformance Control}

Performance control evaluation is on carrying out internal controls and external controls by receiving input from the community. Internal control can be done by checking the service application log. The application log will show how long the application from the community is processed. Agencies can also implement reward and punishment (remuneration system) for employees in providing services.

External control can be done by receiving input from the community. Agencies can provide a platform for the public to report if the services offered are not following the standards. Data collection from the community carried out by distributing questionnaires regularly to the community.

3.5.2.8 Reenginering Business Process towards Best Pratice

The simplification of the business process here is to facilitate the community in submitting applications, such as filling out forms and other requirements. The resident records of each community have collected in the District data warehouse. Therefore, it makes the community more comfortable to apply. They only need 
to show their ID Number, and then the officers can the village, matching permits for a Building immediately search for their data following the ID Establishment, and others. The output from validation Number provided by the applicant.

\subsubsection{Recommendation SPBE Services}

Optimizing the implementation of PATEN public services needs to done to improve the quality of public services. Services provided for improvement advice are public services that interact directly with the community. This improvement aims to improve the quality of service standards regulated for the SPBE Services Domain described in Table 15.

\begin{tabular}{cl}
\multicolumn{1}{c}{ Table 15. Recommendation SPBE Services } \\
\hline No & \multicolumn{1}{c}{ Recommendations } \\
\hline 1 & Strengthening Existing Applications \\
2 & Creating an Online Queue Application System \\
3 & Simplification of Validation System Services \\
4 & Maintenance of the System (Hardware and Software) \\
5 & Improving the Online Complaints System \\
6 & Development of a Public Service Website System \\
7 & Evaluation of Information Dissemination \\
\hline
\end{tabular}

\subsubsection{Strengthening Existing Applications}

Existing application services received in PATEN bureaucracy services are at the information level. Improving to the next level, and it is required to strengthen the application of each service by building platforms that are more interactive and innovative. One of them is by building public service portals and government administration service portals, SPBE service integration, and applying service management and service technology that is relevant and targeted.

\subsubsection{Creating an Online Queue Application System}

The queue system implemented in the Sub-District is still done manually, where the community must come to the location for queuing. Based on comments received through online media, the community complained about the unordered queuing system, where people who arrived earlier received service later.

The improvements that can be done to overcome these problems is by implementing innovations in the form of an Online Queue Application System. The application is a system used to manage public service queues online. This mobile-based system makes the people unnecessary to take the queue number at the location, but rather by ordering the queue number through the application. The Online Queue System can also overcome the problem of unordered queue numbers because the people can monitor the queue through the app.

\subsubsection{Simplification of Validation System Services}

The implementation of the validation process still uses public service system that used to give information a manual system, which means that the community disposition letters, identity cards, family cards, and must go to the relevant institutions to make the other recommendations. The development of an online validation process, such as arranging a cover letter from service system aims to make it easier for the public to 
know the status of the results, and the system can assessed domains, namely governance, and services. provide notification of the state of the application The governance domain gets an index value of 2.00 submitted, whether it is processed, pending, or ready to with the predicate "Average", where the governance of be taken.

\subsubsection{Evaluation of Information Dissemination}

the use of general applications has implemented in part from the Sub-District. Service Domain gets an index value of 0.93 with the predicate "Poor", and there are Information dissemination on the Sub-District Public still five public services that are not yet supported by Service Portal has been done through websites, leaflets, the application system. The output of this research and social media. Based on the results of the prioritizes recommendations for improving the level of information dissemination survey, the official website SPBE maturity in the form of improved indicators, of the Sub-District has provided information on governance recommendations, and SPBE service profiles, service procedures, announcements, and the recommendations.

latest news. While in the department, the Sub-District has provided leaflets and notice boards on the service process device. Social media platforms like Facebook and Instagram used to share information about daily activities in the Sub-District.

The problem discovered in the Sub-District is that the social media platform rarely updates and posts about the mechanism and procedure for PATEN service requirements. Given the role of social media in the Industrial 4.0 and ICT era plays a vital role in the dissemination of information. Social media can also use as a medium of communication and interaction with the community.

The solution for improvement is to design a social media army team to be active in managing the SubDistrict social media platform. His team has the responsibility to always update information, news, and be active in building interactions with the community, such as replying to comments about community complaints. Posts regarding the PATEN service flow mechanism must accomplish. The purpose is to make it easier for the public to know the current process flow and conditions on public services and also to minimize errors in the department in preparing files.

\section{Conclusion}

Electronic-based government system evaluation or called SPBE in the Sub-District public services conducted in this study performed pretty well. The assessment process by mapping the SPBE framework to get the SPBE indicators applied at the Sub-District level. The results of the mapping of all SPBE assessment indicators, there are four indicators from two domains that correspond to the PATEN service used in SPBE assessment in the District. Data collection using a general questionnaire and a maturity level questionnaire.

The results showed that the implementation of an electronic-based government system in the public service PATEN Sub-District produced a level of SPBE maturity that obtained a total index value of 1.47 with the predicate "Poor". Based on the calculation of the results of the questionnaire, the level of maturity of the

\section{Acknowledgements}

The author would like to thank the Ministry of Research, Technology, and Higher Education at Udayana University for funding this research. Thanks to the Sub-District of South Kuta for contributing to the implementation of the SPBE research.

\section{References}

1] H. Hamirul. 2018. "The Pathology of Public Service in the Industrial Revolution Era 4.0". Jurnal Ilmiah Tata Sejuta STIA Mataram, 4 (2), pp.1-16, doi: https://doi.org/10.32666/tatasejuta.v4i2.37.

[2] A. Hidayatno, A. Rahmawan Destyanto, C. Arauna Hulu. 2019. "Industry 4.0 Technology Implementation Impact to Industrial Sustainable Energy in Indonesia: A Model Conceptualization". Energy Procedia, 156, pp.227-233, doi: https://doi.org/10.1016/j.egypro.2018.11.133.

[3] Ombudsmas RI, 2018. Proyeksi Pelayanan Publik ERA 4.0. [Online]. Available at: https://ombudsman.go.id/artikel/r/artikel-proyeksi-pelayanan-publik-era-40. [Accessed 02 Oct 2019]

[4] A. Pratama. 2019, "The landscape of public service innovation in Indonesia: A comprehensive analysis of its characteristic and trend". Innovation \& Management Review, 17 (1), pp.25-40, doi: https://doi.org/10.1108/INMR-11-2018-0080.

[5] Yusriadi, U. Farida. 2019. "Bureaucracy Performance in Public Services in Indonesia". Jurnal Administrare: Jurnal Pemikiran Ilmiah dan Pendidikan Administrasi Perkantoran, 6 (1), pp.1724, doi: https://doi.org/10.26858/ja.v6i1.9434.

[6] N. Nuriyanto. 2014. "Penyelenggaraan Pelayanan Publik Di Indonesia, Sudahkah Berlandaskan Konsep "Welfare State"?, Jurnal Konstitusi, $11 \quad$ (3), pp.428-453, doi: https://doi.org/10.31078/jk\%25x.

[7] Pemerintah Indonesia. 2009. "Undang-Undang Republik Indonesia No. 25 Tahun 2009 tentang Pelayanan Publik". Lembaran RI Tahun 2009 No. 5038. Sekretariat Negara. Jakarta.

[8] A. Lukman Saputra, H. Juliani, N. Saadah. 2017. "Implementasi Peraturan Menteri Dalam Negeri Nomor 4 Tahun 2010 tentang Pedoman Pelayanan Administrasi Terpadu Kecamatan (PATEN) Di Kecamatan Kendal Kabupaten Kendal". Diponegoro Law Journal, 6 (1), pp.1-21.

[9] Y. Indarto, A. Suryono, B. Haryono. 2010. “The Implementation of "Pe layanan Administration Terpadu Kecamatan ( PATEN ) to Improve Quality of Public Service : A Study on the Implementation of the 2010 Minister of Domestic Affairs , Decree number 4 about Pelayanan Administrasi Terpadu Kecamatan in Situbondo". International Journal of Management and Administrative Sciences (IJMAS), 4 (5), pp.69-73.

[10]Prof. Sukardi, Ph.D. 2015. "Metodologi Penelitian Pendidikan Tindakan Kelas: Implementasi dan Pengembangannya". Cetakan ke-3. Jakarta: Bumi Aksara.

[11] Kementerian Pendayagunaan Aparatur Negara dan Reformasi Birkorasi. 2018. "Pedoman Evaluasi Sistem Pemerintahan 
I Made Sukarsa, Ida Bagus Ananda Paramartha, Anak Agung Ketut Agung Cahyawan, Kadek Suar Wibawa, Putu Gede Arya Sumertha Yasa, Ni Made Swasti Wulanyani, Ni Wayan Wisswani

RESTI Journal (System Engineering and Information Technology) Vol. 4 No. 2 (2020) 243 - 253

Berbasis Elektronik Instansi Pusat dan Pemerintah Daerah". Nomor 5 Tahun 2018. Jakarta.

[12]Pemerintah Indonesia. 2018. "Peraturan Presiden Republik Indonesia Nomor 95 Tahun 2018 tentang Sistem Pemerintahan Berbasis Elektronik”. Nomor. 95 Tahun 2018. Jakarta.

[13]A. Bouty, M. Koniyo, D. Novian. 2019. "Evaluasi Sistem Pemerintahan Berbasis Elektronik Menggunakan E-Government
Maturity Model (Kasus di Pemerintah Kota Gorontalo)”. Jurnal Penelitian Komunikasi Dan Opini Publik, 23 (1), pp.16-24.

[14]I. Wayan Prasada Bharaditya, I. Made Sukarsa, P. Wira Buana. 2017. "Internal Control Improvement for Creating Good Governance". International Journal of Information Engineering and Electronic Business, 9(3), pp.9-17, doi: 10.5815/ijieeb.2017.03.02. 